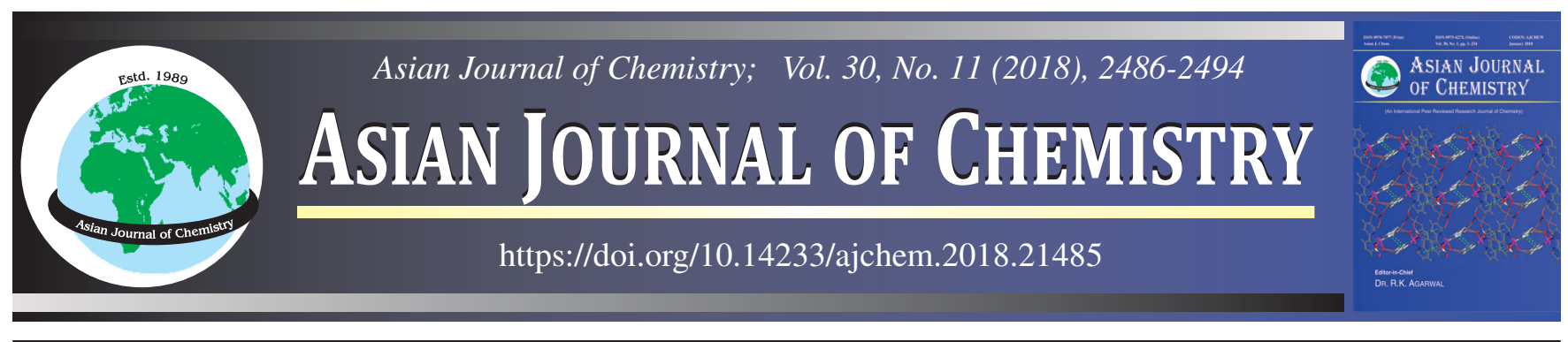

\title{
Synthesis, Characterization, Antimicrobial and DNA Binding Studies of Cobalt(II) Complexes of 4-[(2-Mercapto-phenylimino)methyl]-1,5-dimethyl-2-phenyl-1,2-dihydropyrazol-3-one
}

\section{Jisha SReEdharan ${ }^{1}$, B.N. Anila ${ }^{2}$ and M.K. MuraleEdharan NaIR ${ }^{3, *}$}

${ }^{1}$ Department of Chemistry, Sree Narayana College, Chengannur, Alappuzha-689 508, India

${ }^{2}$ Department of Chemistry, Government College Kottayam, Nattakom, Kottayam-686 013, India

${ }^{3}$ Department of Chemistry, Maharaja's College, Ernakulam-682 011, India

*Corresponding author: E-mail: mkmnair@maharajas.ac.in

The synthesis and characterization of chloro, bromo, iodo, nitrato and perchlorato complexes of Co(II) with an antipyrine based Schiff base ligand, 4-[(2-mercapto-phenylimino)-methyl]-1,5-dimethyl-2-phenyl-1,2-dihydropyrazol-3-one (ATAC), are reported. All the complexes were characterized by elemental analysis, molar conductance in non-aqueous solvents, magnetic moment value, spectroscopic methods such as infrared and electronic as well as thermogravimetry. From the elemental analysis data and molar conductance measurements, the complexes can be formulated as, $\left[\mathrm{Co}(\mathrm{ATAC}) \mathrm{Cl}_{2}\right]$, $\left[\mathrm{Co}(\mathrm{ATAC}) \mathrm{Br}_{2}\right],\left[\mathrm{Co}(\mathrm{ATAC}) \mathrm{I}_{2}\right],\left[\mathrm{Co}(\mathrm{ATAC})_{2}\left(\mathrm{NO}_{3}\right)\right]\left(\mathrm{NO}_{3}\right)$ and $\left[\mathrm{Co}(\mathrm{ATAC})_{2}\left(\mathrm{ClO}_{4}\right)\right]\left(\mathrm{ClO}_{4}\right)$. UV-Visible spectral data and magnetic moment values of complexes suggest a tetrahedral geometry for halide complexes and a distorted octahedral geometry for nitrato and perchlorato complexes. Antimicrobial activity of ligand and Co(II) complexes have been studied on both "Gram-positive" (Bacillus subtilis) and "Gram-negative" (Vibrio salmonella typhi and Escherichia coli,) bacteria and three fungi, viz., Aspergillus fumigatus, Aspergillus niger and Penicillium expansum. The results show that the ligand and the cobalt(II) complexes were significantly active against the tested microorganisms. Absorption spectroscopy, fluorescence spectroscopy and viscosity measurements have been used to study the binding ability of complexes with CT-DNA. The results indicate that the complexes bind with CT-DNA in an intercalative mode.

Keywords: Co(II) complexes, Pyrazol, Magnetic moment, Antimicrobial activity, DNA binding.

ᄂ - - - - - - - - - - - - - - - - - - - - - - - - - - - -

\section{INTRODUCTION}

Syntheses, structural analyses and properties of coordination complexes still arouse considerable research interests because of their potential applications in material science [1]. Schiff bases are widely used organic compounds as pigments, dyes, catalysts, intermediates in organic synthesis and polymer stabilizers [2]. A wide range of metal complexes derived from antipyrine and its derivatives have been reported due to their interesting structural features as well as the biological activities. Antipyrine based metal complexes were found to exhibit antitumor [3,4], antimicrobial [5], antiviral [6] activities and analgesics and anti-inflammatory effects $[7,8]$. The remarkable biological properties of these complexes prompted us to undertake the syntheses of complexes of antipyrine based Schiff base ligand and its biological studies. In the present investigation we synthesized five complexes of Co(II) with the Schiff base ligand 4-[(2-mercapto-phenylimino)methyl]-1,5dimethyl-2-phenyl-1,2-dihydropyrazol-3-one (ATAC). All the complexes were characterized with different analytical, spectroscopic and thermogravimetric analyses. The antimicrobial activities and DNA binding ability for the synthesized complexes were also studied.

\section{EXPERIMENTAL}

The ligand was prepared by the condensation of 4-antipyrinecarboxaldehyde and 2-aminothiophenol, which were purchased from Sigma-Aldrich Chemical Co. USA. For the synthesis of complexes, the metal salts employed were $\mathrm{CoCl}_{2} \cdot 6 \mathrm{H}_{2} \mathrm{O}, \mathrm{CoBr}_{2} \cdot 6 \mathrm{H}_{2} \mathrm{O}$ (both are AR grade), $\mathrm{CoI}_{2} \cdot 6 \mathrm{H}_{2} \mathrm{O}$, $\mathrm{Co}\left(\mathrm{NO}_{3}\right)_{2} \cdot 6 \mathrm{H}_{2} \mathrm{O}$ and $\mathrm{Co}\left(\mathrm{ClO}_{4}\right)_{2} \cdot 6 \mathrm{H}_{2} \mathrm{O}$. For DNA binding studies, calf thymus-DNA (CT-DNA) was supplied by Sigma Aldrich Chemical Co. USA and tris $\mathrm{HCl}$, ethidium bromide and $\mathrm{NaCl}$ were AR grade.

This is an open access journal, and articles are distributed under the terms of the Creative Commons Attribution-NonCommercial 4.0 International (CC BY-NC 4.0) License, which allows others to copy and redistribute the material in any medium or format, remix, transform, and build upon the material, as long as appropriate credit is given and the new creations are licensed under the identical terms. 
Physico-chemical methods: Complexometric titration [9] was carried out in order to estimate the amount of cobalt in complexes. Halide and perchlorate content was estimated by Volhards method [9] and Kurz's [10] method respectively. The elemental analyses of the complexes were done using a HeraeusCHNS-Rapid analyzer. Systronics Conductivity Bridge with a dip conductance cell was used to measure the molar conductance of $10^{-3} \mathrm{M}$ solutions of complexes. The IR spectra were recorded using Shimadzu FTIR 8400S spectrophotometer in the range $4000-400 \mathrm{~cm}^{-1}$ using $\mathrm{KBr}$ pellet technique and in Bruker IFS 66v FTIR spectrometer in the range $500-100 \mathrm{~cm}^{-1}$ using polyethylene powder. The solid-state electronic spectra of ligand and complexes were taken on a Shimadzu UV-visible spectrometer UV-2450 in the range 200-800 nm. Magnetic moment values were determined by using Sherwood Scientific Magnetic Susceptibility balance at room temperature. The thermal experiments were carried out, using Shimadzu DTG60 thermal analyzer, in the atmosphere of dry nitrogen, from room temperature to about $800^{\circ} \mathrm{C}$, with a heating rate of $10{ }^{\circ} \mathrm{C}$ per min.

Preparation of $\mathbf{C o}$ (II) complexes: A suspension of ligand ATAC $(0.9702 \mathrm{~g})$ in ethyl acetate $(100 \mathrm{~mL})$ was refluxed on a steam bath. To the boiling suspension $\mathrm{Co}$ (II) salts $(0.0 .5488 \mathrm{~g}$ of $\mathrm{Co}\left(\mathrm{ClO}_{4}\right)_{2} \cdot 6 \mathrm{H}_{2} \mathrm{O}, 0.4370 \mathrm{~g}$ of $\mathrm{Co}\left(\mathrm{NO}_{3}\right)_{2} \cdot 6 \mathrm{H}_{2} \mathrm{O}, 0.6312 \mathrm{~g}$ of $\mathrm{CoI}_{2} \cdot 6 \mathrm{H}_{2} \mathrm{O}, 0.49 .2 \mathrm{~g}$ of $\mathrm{CoBr}_{2} \cdot 6 \mathrm{H}_{2} \mathrm{O}$ or $0.3568 \mathrm{~g} \mathrm{CoCl}_{2} \cdot 6 \mathrm{H}_{2} \mathrm{O}$ ) in methanol $(10 \mathrm{~mL})$ were added drop by drop. The mixture was refluxed for $4 \mathrm{~h}$ on a steam bath. The precipitated complexes were filtered and washed repeatedly with hot ethyl acetate. Ethanol recrystallized complexes were dried over $\mathrm{P}_{4} \mathrm{O}_{10}$ under vacuum.

Antimicrobial studies: The in vitro evaluation of antimicrobial activities of $\mathrm{Co}$ (II) complexes were tested against certain human pathogenic bacteria and fungi by well diffusion method. $10^{-3} \mathrm{M}$ solutions of all the complexes in DMSO were used. Both the "Gram-positive" (Bacillus subtilis) and "Gramnegative" (Vibrio Salmonella typhi and Escherichia coli) bacteria were grown in nutrient agar medium and incubated at $37{ }^{\circ} \mathrm{C}$ for $48 \mathrm{~h}$ and were used as test bacteria. The fungi, Aspergillus fumigatus, Aspergillus niger and Penicillium expansum were grown in potato dextrose agar medium, incubated at $27^{\circ} \mathrm{C}$ for $72 \mathrm{~h}$ and were used as test fungus. Then, the petri-dishes were inoculated with a loop full of bacterial or fungal culture and spread it uniformly throughout with a sterile glass spreader. The test samples $(10 \mathrm{mg} / \mathrm{mL})$ and reference antibiotic were added with a sterile micropipette in the wells of each plate. The plates were then incubated at $35 \pm 2{ }^{\circ} \mathrm{C}$ and $27 \pm 1^{\circ} \mathrm{C}$, for $24-48 \mathrm{~h}$, for bacteria and fungus, respectively. The antimicrobials present in the samples were allowed to diffuse out into the medium and interact in a plate freshly seeded with the test organisms. The resulting zones of inhibition will be uniformly circular as there will be a confluent lawn of growth. The diameter of zone of inhibition measured in $\mathrm{mm}$.

DNA binding studies: All DNA binding experiments were performed with Calf Thymus-DNA (CT-DNA), in Tris(hydroxymethyl)aminomethane-HCl (Tris-HCl) buffer solution ( $\mathrm{pH}=7.2$ ), prepared using deionized water.

Electronic spectral studies: Solutions of DNA in Tris$\mathrm{HCl}$ buffer gave a ratio of UV absorbance at 260 and $280 \mathrm{~nm}$
(A260/A280) of 1.8, indicating that the DNA was sufficiently free of protein. The concentration of CT-DNA was determined from its absorbance at $260 \mathrm{~nm}$ using $\varepsilon_{260}=6600 \mathrm{~L} \mathrm{~mol}^{-1} \mathrm{~cm}^{-1}$. Stock solutions of DNA were stored at $4{ }^{\circ} \mathrm{C}$ and used within 4 days. The stock solutions of the complexes were prepared by dissolving the complexes in DMF and diluting suitably with Tris-HCl buffer to required concentrations for all the experiments (1 \% DMF and $99 \%$ Tris-HCl). The absorption spectral titration experiment was performed by keeping the concentration of the complexes constant $(25 \mu \mathrm{M})$ with varying CT-DNA concentration (10 to $50 \mu \mathrm{M})$. Equal volumes of solutions of CT-DNA were added to the complex and reference solutions to eliminate the absorbance of CT-DNA itself.

Fluorescence measurements: The fluorescence emission spectra have been confirmed to be effective for characterizing the binding mode of metal complexes to DNA [11-14]. The emission spectrum is obtained by setting the excitation monochromator at the maximum excitation wavelength and scanning with emission monochromator. Generally, an excitation spectrum is first made in order to confirm the identity of the substance and to select the optimum excitation wavelength. To confirm the interaction between the complexes and CTDNA, an ethidium bromide (EB) fluorescence displacement experiment was carried out. Ethidium bromide is a planar cationic dye that is widely used as a sensitive fluorescence for probe for DNA. Ethidium bromide emits intense fluorescent light in the presence of DNA due to its strong intercalation between adjacent DNA base pairs. The displacement technique is based on a decrease of this fluorescence resulting from the displacement of ethidium bromide from the DNA sequence by a quencher. The method therefore provides indirect evidence for an intercalative binding mode. The quenching extent of fluorescence of ethidium bromide bound to DNA is used to determine the extent of binding between the quencher and DNA [15]. Quenching studies were carried out with an excitation wavelength of $250 \mathrm{~nm}$ and emission wavelength $280-600 \mathrm{~nm}$.

Viscosity measurements: Viscosity determination was carried out using a Schott Gerate AVS 310 automated viscometer that was thermostated at $25^{\circ} \mathrm{C}$ in a constant temperature bath. Viscosity of the DNA $(50 \mu \mathrm{M})$ was examined in the absence and presence of increasing concentrations $(60-500 \mu \mathrm{M})$ of complexes. Flow time was measured with a digital stop, watch and each sample was measured three times and an average flow time was calculated.

\section{RESULTS AND DISCUSSION}

All the halo complexes of $\mathrm{Co}(\mathrm{II})$ were blue in colour while nitrato and perchlorato complexes have pink colour and are fine powder. All the complexes are soluble in methanol, ethanol, acetone, DMF, DMSO and insoluble in benzene and toluene.

Carbon, nitrogen, hydrogen, halide [9], perchlorate [10] and metal percentage in $\mathrm{Co}$ (II) complexes were determined and presented in Table-1. The data suggest that the complexes can be formulated as [Co(ATAC) $\mathrm{X}_{2}$ ], where $\mathrm{X}=\mathrm{Cl}^{-}, \mathrm{Br}^{-}$or I$\left[\mathrm{Co}(\mathrm{ATAC})_{2}\left(\mathrm{NO}_{3}\right)\right]\left(\mathrm{NO}_{3}\right)$ and $\left[\mathrm{Co}(\mathrm{ATAC})_{2}\left(\mathrm{ClO}_{4}\right)\right]\left(\mathrm{ClO}_{4}\right)$.

Electrical conductance: Non-aqueous solvents viz., dimethyl formamide, acetonitrile and nitrobenzene was used 
TABLE-1

ANALYTICAL DATA OF Co(II) COMPLEXES OF ATAC

\begin{tabular}{|c|c|c|c|c|c|c|c|}
\hline \multirow{2}{*}{ Complex } & \multicolumn{6}{|c|}{ Elemental analysis (\%): Found (calcd.) } & \multirow{2}{*}{ Yield (\%) } \\
\hline & M & $\mathrm{C}$ & $\mathrm{H}$ & $\mathrm{N}$ & $\mathrm{S}$ & Anion & \\
\hline$\left[\mathrm{Co}(\mathrm{ATAC}) \mathrm{Cl}_{2}\right]$ & $12.66(13.06)$ & $47.85(47.91)$ & $3.01(3.35)$ & $9.03(9.31)$ & $7.11(6.93)$ & $16.63(15.64)$ & 79 \\
\hline$\left[\mathrm{Co}(\mathrm{ATAC}) \mathrm{Br}_{2}\right]$ & $10.56(10.91)$ & $39.89(40.03)$ & $2.53(2.80)$ & $7.55(7.78)$ & $5.79(5.94)$ & $29.90(29.59)$ & 71 \\
\hline$\left[\mathrm{Co}(\mathrm{ATAC}) \mathrm{I}_{2}\right]$ & $9.00(9.26)$ & $33.85(34.09)$ & $2.01(2.38)$ & $6.50(6.63)$ & $4.98(5.06)$ & $39.05(40.02)$ & 68 \\
\hline$\left[\mathrm{Co}(\mathrm{ATAC})_{2}\left(\mathrm{NO}_{3}\right)\right]\left(\mathrm{NO}_{3}\right)$ & $6.85(7.13)$ & $52.13(52.36)$ & $3.44(3.67)$ & $13.25(13.57)$ & $7.67(7.76)$ & - & 77 \\
\hline$\left[\mathrm{Co}(\mathrm{ATAC})_{2}\left(\mathrm{ClO}_{4}\right)\right]\left(\mathrm{ClO}_{4}\right)$ & $6.32(6 . .54)$ & $47.89(48.00)$ & $3.31(3.35)$ & $9.13(9.33)$ & $7.00(7.12)$ & $22.01(21.91)$ & 69 \\
\hline
\end{tabular}

as solvents for determining the electrical conductance of the $\mathrm{Co}$ (II) complexes. The molar conductance data presented in Table-2, shows that all the halide complexes behave as nonelectrolytes whereas nitrate and perchlorate complexes shows 1:1 electrolytic behaviour [16]. Therefore the complexes can be formulated as [Co(ATAC) $\left.\left.\mathrm{Cl}_{2}\right)\right]$, [Co(ATAC) $\mathrm{Br}_{2}$ ], [Co(ATAC) $\mathrm{I}_{2}$, $\left[\mathrm{Co}(\mathrm{ATAC})_{2}\left(\mathrm{NO}_{3}\right)\right]\left(\mathrm{NO}_{3}\right)$ and $\left[\mathrm{Co}(\mathrm{ATAC})_{2}\left(\mathrm{ClO}_{4}\right)\right]\left(\mathrm{ClO}_{4}\right)$.

Infrared spectral studies: Binding mode of Schiff base to the metal ion in complexes were studied by the comparison of IR spectra of ligand and complexes. The strong intense peak at $1658 \mathrm{~cm}^{-1}$ in the spectrum of ligand is attributed to the stretching vibration of pyrazolone carbonyl group [17] is found to be shifted to $1600-1598 \mathrm{~cm}^{-1}$ in all the complexes indicating the coordination of carbonyl oxygen. The $\mathrm{CH}=\mathrm{N}$ stretching frequency of pure ligand $\left(1593 \mathrm{~cm}^{-1}\right)$ is shifted to the region $1581-1571 \mathrm{~cm}^{-1}$, showing coordination of azomethine nitrogen to the metal [18]. The presence of additional non ligand bands in the spectra of all the complexes around 550-555 and 451$455 \mathrm{~cm}^{-1}$ are assignable to the $\mathrm{M}-\mathrm{O}$ and $\mathrm{M}-\mathrm{N}$ stretching frequencies respectively [19].

The nitrato complex exhibits vibrational frequencies characteristics of both coordinated and uncoordinated nitrate ions. A very strong band at $1384 \mathrm{~cm}^{-1}$ and a medium at 825 $\mathrm{cm}^{-1}$ are attributed to the $v_{3}$ and $v_{4}$ vibrations, respectively, of ionic nitrate of $\mathrm{D}_{3 \mathrm{~h}}$ symmetry [20,21]. The presence of coordinated nitrate is indicated by two bands at 1408 and $1213 \mathrm{~cm}^{-1}$ due to the $v_{4}$ and $v_{1}$ vibrations, respectively, of the coordinated nitrate of $C_{2 v}$ symmetry [22]. Since $\left(v_{4}-v_{1}\right)=195 \mathrm{~cm}^{-1}$, the nitrate ion is coordinated in a bidentate fashion $[23,24]$.
In the perchlorato complex, the triply split band maxima observed at 1143,1116 and $1026 \mathrm{~cm}^{-1}$ are due to the $v_{8}, v_{6}$ and $v_{1}$ vibrations of perchlorate ions of $\mathrm{C}_{2 \mathrm{v}}$ symmetry indicating the coordination of perchlorate ion in a bidentate fashion $[11,25]$. Also the presence of a strong band at $1087 \mathrm{~cm}^{-1}$ is attributed to the vibrations of uncoordinated perchlorate ion of $\mathrm{T}_{\mathrm{d}}$ symmetry [26]. The bands observed at 910 and $688 \mathrm{~cm}^{-1}$ due to $v_{2}$ and $v_{3}$ vibrations respectively of coordinated perchlorate $C_{2 v}$ ion. The band at $625 \mathrm{~cm}^{-1}$ due to the $v_{4}$ vibrations of uncoordinated perchlorate $T_{d}$ ion also support coexistence of both coordinated and uncoordinated perchlorate ion in the complex $[11,27]$.

In the far infrared spectra of the halide complexes, the bands at 285,233 and $195 \mathrm{~cm}^{-1}$ are due to the $v(\mathrm{Co}-\mathrm{Cl}), v(\mathrm{Co}-\mathrm{Br})$ and $v(\mathrm{Co}-\mathrm{I})$ vibrations respectively [19] which are absent in the ligand spectrum. The important infrared spectral bands of ligand ATAC and its $\mathrm{Co}$ (II) complexes together with the tentative assignments are summarized in the Table- 3 .

Electronic spectra: The electronic spectral data with tentative assignment of the $\mathrm{Co}$ (II) complexes of ATAC are presented in Table-4. In all Co(II) complexes, both $\mathrm{n} \rightarrow \pi^{*}$ and $\pi \rightarrow \pi^{*}$ are shifted to lower frequency region $29154-29673 \mathrm{~cm}^{-1}$ and $33444-$ $36231 \mathrm{~cm}^{-1}$ respectively, compared to the ligand ATAC [28]. This indicates the presence of coordination of carbonyl oxygen and azomethine to the central metal atom. All the complexes exhibit an intense absorption band at $29325-30303 \mathrm{~cm}^{-1}$ region, which may be due to the charge transfer transitions [29]. In the case of halo complexes, three closely spaced weak bands in the region $14705-17953 \mathrm{~cm}^{-1}$ which are assigned to the ${ }^{4} \mathrm{~A}_{2}(\mathrm{~F})$ $\rightarrow{ }^{4} \mathrm{~T}_{1}(\mathrm{P})$ transition for a tetrahedral symmetry around the

TABLE-2

MOLAR CONDUCTANCE DATA $\left(\mathrm{ohm}^{-1} \mathrm{~cm}^{2} \mathrm{~mol}^{-1}\right)$ OF Co(II) COMPLEXES (10-3 M SOLUTION) OF ATAC

\begin{tabular}{lcccc}
\hline \multirow{2}{*}{ Complexes } & & Molar conductance & Type of electrolyte \\
\cline { 2 - 5 } & Nitrobenzene & DMF & Methanol & Non electrolyte \\
\hline$\left[\mathrm{Co}(\mathrm{ATAC}) \mathrm{Cl}_{2}\right]$ & - & 11 & 21 & Non electrolyte \\
{$\left[\mathrm{Co}(\mathrm{ATAC}) \mathrm{Br}_{2}\right]$} & - & 18 & 24 & Non electrolyte \\
{$\left[\mathrm{Co}(\mathrm{ATAC}) \mathrm{I}_{2}\right]$} & - & 12 & 243 & $1: 1$ electrolyte \\
{$\left[\mathrm{Co}(\mathrm{ATAC})_{2}\left(\mathrm{NO}_{3}\right)\right]\left(\mathrm{NO}_{3}\right)$} & 50 & 160 & 110 & $1: 1$ electrolyte \\
{$\left[\mathrm{Co}(\mathrm{ATAC})_{2}\left(\mathrm{ClO}_{4}\right)\right]\left(\mathrm{ClO}_{4}\right)$} & 23 & 75 & & \\
\hline
\end{tabular}

TABLE-3

IR SPECTRAL BANDS OF Co(II) COMPLEXES OF ATAC WITH TENTATIVE ASSIGNMENTS

\begin{tabular}{|c|c|c|c|c|c|c|}
\hline ATAC & {$\left[\mathrm{Co}(\mathrm{ATAC}) \mathrm{Cl}_{2}\right]$} & [Co(ATAC)Br $\left.{ }_{2}\right]$ & {$\left[\mathrm{Co}(\mathrm{ATAC}) \mathrm{I}_{2}\right]$} & {$\left[\mathrm{Co}(\mathrm{ATAC})_{2}\left(\mathrm{NO}_{3}\right)\right]\left(\mathrm{NO}_{3}\right)$} & {$\left[\mathrm{Co}(\mathrm{ATAC})_{2}\left(\mathrm{ClO}_{4}\right)\right]\left(\mathrm{ClO}_{4}\right)$} & Assignments \\
\hline 1658 & 1600 & 1600 & 1600 & 1598 & 1598 & $v(\mathrm{C}=\mathrm{O})$ \\
\hline 1593 & 1571 & 1571 & 1575 & 1581 & 1581 & $v(\mathrm{HC}=\mathrm{N})$ \\
\hline- & 285 & - & - & - & - & $v(\mathrm{Co}-\mathrm{Cl})$ \\
\hline- & - & 233 & - & - & - & $v(\mathrm{Co}-\mathrm{Br})$ \\
\hline- & - & - & 195 & - & - & $v(\mathrm{Co}-\mathrm{I})$ \\
\hline- & 551 & 554 & 552 & 555 & 552 & $v(\mathrm{Co}-\mathrm{O})$ \\
\hline- & 452 & 453 & 452 & 451 & 455 & $v(\mathrm{Co}-\mathrm{N})$ \\
\hline
\end{tabular}




\begin{tabular}{|c|c|c|c|}
\hline \multicolumn{4}{|c|}{$\begin{array}{c}\text { TABLE-4 } \\
\text { ELECTRONIC SPECTRAL DATA AND MAGNETIC MOMENT VALUES OF Co(II) COMPLEXES OF ATAC }\end{array}$} \\
\hline Complexes & Absorption maxima $\left(\mathrm{cm}^{-1}\right)$ & Tentative Assignments & $\mu_{\mathrm{eff}}(\mathrm{BM})$ \\
\hline ATAC & $\begin{array}{l}29850 \\
38610\end{array}$ & $\begin{array}{l}\mathrm{n} \rightarrow \pi^{*} \\
\pi \rightarrow \pi^{*}\end{array}$ & - \\
\hline$\left[\mathrm{Co}(\mathrm{ATAC}) \mathrm{Cl}_{2}\right]$ & $\left.\begin{array}{l}29239 \\
33444 \\
29940 \\
15822 \\
16051 \\
17953\end{array}\right\}$ & $\begin{array}{l}\mathrm{n} \rightarrow \pi^{*} \\
\pi \rightarrow \pi^{*} \\
\text { Charge Transfer } \\
{ }^{4} \mathrm{~A}_{2}(\mathrm{~F}) \rightarrow{ }^{4} \mathrm{~T}_{1}(\mathrm{P})\end{array}$ & 4.20 \\
\hline$\left[\mathrm{Co}(\mathrm{ATAC}) \mathrm{Br}_{2}\right]$ & $\left.\begin{array}{l}29411 \\
35842 \\
30303 \\
15455 \\
15948 \\
17211\end{array}\right\}$ & $\begin{array}{l}\mathrm{n} \rightarrow \pi^{*} \\
\pi \rightarrow \pi^{*} \\
\text { Charge Transfer } \\
{ }^{4} \mathrm{~A}_{2}(\mathrm{~F}) \rightarrow{ }^{4} \mathrm{~T}_{1}(\mathrm{P})\end{array}$ & 4.15 \\
\hline $\left.\operatorname{Co}(\mathrm{ATAC}) \mathrm{I}_{2}\right]$ & $\left.\begin{array}{l}29673 \\
33670 \\
29325 \\
14705 \\
15576 \\
16313\end{array}\right\}$ & $\begin{array}{l}\mathrm{n} \rightarrow \pi^{*} \\
\pi \rightarrow \pi^{*} \\
\text { Charge Transfer } \\
{ }^{4} \mathrm{~A}_{2}(\mathrm{~F}) \rightarrow{ }^{4} \mathrm{~T}_{1}(\mathrm{P})\end{array}$ & 4.17 \\
\hline$\left[\mathrm{Co}(\mathrm{ATAC})_{2}\left(\mathrm{NO}_{3}\right)\right]\left(\mathrm{NO}_{3}\right)$ & $\begin{array}{c}29239 \\
36066 \\
30303 \\
19157 \\
18867 \\
9476 \\
\end{array}$ & $\begin{array}{l}\mathrm{n} \rightarrow \pi^{*} \\
\pi \rightarrow \pi^{*} \\
\text { Charge Transfer } \\
{ }^{4} \mathrm{~T}_{1 \mathrm{~g}}(\mathrm{~F}) \rightarrow{ }^{4} \mathrm{~T}_{1 \mathrm{~g}}(\mathrm{P}) \\
{ }^{4} \mathrm{~T}_{1 \mathrm{~g}}(\mathrm{~F}) \rightarrow{ }^{4} \mathrm{~A}_{2 \mathrm{~g}}(\mathrm{~F}) \\
{ }^{4} \mathrm{~T}_{1 \mathrm{~g}}(\mathrm{~F}) \rightarrow{ }^{4} \mathrm{~T}_{2 \mathrm{~g}}(\mathrm{~F})\end{array}$ & 4.85 \\
\hline$\left[\mathrm{Co}(\mathrm{ATAC})_{2}\left(\mathrm{ClO}_{4}\right)\right]\left(\mathrm{ClO}_{4}\right)$ & $\begin{array}{c}29154 \\
36231 \\
29940 \\
19041 \\
18587 \\
9225 \\
\end{array}$ & $\begin{array}{l}\mathrm{n} \rightarrow \pi^{*} \\
\pi \rightarrow \pi^{*} \\
\text { Charge Transfer } \\
{ }^{4} \mathrm{~T}_{1 \mathrm{~g}}(\mathrm{~F}) \rightarrow{ }^{4} \mathrm{~T}_{1 \mathrm{~g}}(\mathrm{P}) \\
{ }^{4} \mathrm{~T}_{1 \mathrm{~g}}(\mathrm{~F}) \rightarrow{ }^{4} \mathrm{~A}_{2 \mathrm{~g}}(\mathrm{~F}) \\
{ }^{4} \mathrm{~T}_{1 \mathrm{~g}}(\mathrm{~F}) \rightarrow{ }^{4} \mathrm{~T}_{2 \mathrm{~g}}(\mathrm{~F}) \\
\end{array}$ & 4.93 \\
\hline
\end{tabular}

$\mathrm{Co}(\mathrm{II})$ ion $[28,30]$. The spectral line splitting originates from the reduction of orbital degeneracy due to the difference in strength of ligand and halide ions and restricted bond angle of the $\mathrm{O}-\mathrm{Co}-\mathrm{N}$ entity [31,32].

The nitrato and perchlorato complexes shows the presence of three bands in the regions 9225-9476, 18587-18867 and 19041-19157 $\mathrm{cm}^{-1}$ corresponding to the transitions ${ }^{4} \mathrm{~T}_{1 \mathrm{~g}}(\mathrm{~F}) \rightarrow$ ${ }^{4} \mathrm{~T}_{2 \mathrm{~g}}(\mathrm{~F}),{ }^{4} \mathrm{~T}_{1 \mathrm{~g}}(\mathrm{~F}) \rightarrow{ }^{4} \mathrm{~A}_{2 \mathrm{~g}}(\mathrm{~F})$ and ${ }^{4} \mathrm{~T}_{1 \mathrm{~g}}(\mathrm{~F}) \rightarrow{ }^{4} \mathrm{~T}_{1 \mathrm{~g}}(\mathrm{P})$. These transitions, which are characteristic of a six coordinate high spin complex with a distorted octahedral geometry, suggests a distorted octahedral geometry around the Co(II) ion in nitrate and perchlorate complexes [33,34].

Magnetic behaviour: The magnetic moment values of the halide complexes was observed in the range 4.15-4.20 BM suggesting tetrahedral geometry around the Co(II) ion [35]. Furthermore, the magnetic moment values of nitrate and perchlorate complexes were found at 4.85 and $4.93 \mathrm{BM}$, respectively, indicating the presence of three unpaired electrons per Co(II) ion in weak field distorted octahedral environment [34]. The magnetic moments of all the $\mathrm{Co}$ (II) complexes are given in Table-4 along with electronic spectral data.

Thermogravimetric analyses: The thermal decomposition data of the four complexes of Co(II) ion are given in Table-5. The thermal analysis of the perchlorate complex was not possible due to its explosive nature.
The chloro complex undergoes one stage decomposition process. The complex is stable upto $380{ }^{\circ} \mathrm{C}$. There is no mass loss up to this temperature indicating the absence of water or any solvent molecule in the complex. The decomposition starts at $380{ }^{\circ} \mathrm{C}$ and ends at $500{ }^{\circ} \mathrm{C}$, with maximum mass loss at 446 ${ }^{\circ} \mathrm{C}$, as indicated by the DTG peak. Two chloride ions and one molecule of ATAC, both decomposes in the single stage with the mass loss $79.78 \%$. The final residue corresponds to anhydrous $\mathrm{CoO}$.

The bromo complex is thermally stable up to $380{ }^{\circ} \mathrm{C}$ and the complex undergoes a three stage decomposition process. The first stage starts at $380{ }^{\circ} \mathrm{C}$ and ends at $390^{\circ} \mathrm{C}$. There is no coordinated water or solvent molecule. The observed mass loss is $14.28 \%$ is due to the loss of one bromide ion with DTG peak at $384{ }^{\circ} \mathrm{C}$. The second stage occurs between 390 and $400{ }^{\circ} \mathrm{C}$ corresponding to the loss of the second bromide ion, with mass loss $14.60 \%$ and DTG peak appears at $396^{\circ} \mathrm{C}$. The third stage decomposition starts at $400{ }^{\circ} \mathrm{C}$ and ends at $500{ }^{\circ} \mathrm{C}$ corresponding to the mass loss of one molecule of ATAC (mass loss $53.20 \%$ ) leaving $\mathrm{CoO}$ as the final residue. The DTG curve occurs at $441^{\circ} \mathrm{C}$.

The iodo complex decomposes around $350^{\circ} \mathrm{C}$, which indicates the absence of water or any solvent molecule in the complex. The first stage starts at $350{ }^{\circ} \mathrm{C}$ and ends at $385{ }^{\circ} \mathrm{C}$ with a mass loss $19.98 \%$ resulting in the loss of one iodide 
TABLE-5

PHENOMENOLOGICAL DATA FOR THE THERMAL DECOMPOSITION OF THE Co(II) COMPLEXES OF ATAC

\begin{tabular}{|c|c|c|c|c|c|c|c|}
\hline \multirow{2}{*}{ Complexes } & \multirow{2}{*}{$\begin{array}{l}\text { Stages of } \\
\text { decompo- } \\
\text { sition }\end{array}$} & \multirow{2}{*}{$\begin{array}{l}\text { Temp. } \\
\left({ }^{\circ} \mathrm{C}\right)\end{array}$} & \multirow{2}{*}{$\begin{array}{l}\text { DTG } \\
\text { peak }\end{array}$} & \multirow{2}{*}{$\begin{array}{l}\text { Residual } \\
\text { species }\end{array}$} & \multirow{2}{*}{ Decomposition species } & \multicolumn{2}{|c|}{ Total mass loss $(\%)$} \\
\hline & & & & & & Observed & Calculated \\
\hline$\left[\mathrm{Co}(\mathrm{ATAC}) \mathrm{Cl}_{2}\right]$ & $\mathrm{I}$ & $380-500$ & 446 & $\mathrm{CoO}$ & Two chloride ions and one molecule ATAC & 79.78 & 79.81 \\
\hline \multirow{3}{*}[\mathrm{Co}(\mathrm{ATAC})\mathrm{Br}_{2}]{} & I & $380-390$ & 384 & \multirow{3}{*}{$\mathrm{CoO}$} & One bromide ion & 14.28 & 14.80 \\
\hline & II & $390-400$ & 396 & & One bromide ion & 14.60 & 14.80 \\
\hline & III & $400-500$ & 441 & & One molecule ATAC & 53.20 & 53.59 \\
\hline \multirow{2}{*}[\mathrm{Co}(\mathrm{ATAC})\mathrm{I}_{2}]{} & I & $350-385$ & 361 & \multirow{2}{*}{$\mathrm{CoO}$} & One iodide ion & 19.98 & 20.26 \\
\hline & II & $390-490$ & 425 & & One iodide ion and one molecule ATAC & 65.01 & 65.24 \\
\hline \multirow{2}{*}[\mathrm{Co}(\mathrm{ATAC})_{2}(\mathrm{NO}_{3})]{$\left(\mathrm{NO}_{3}\right)$} & I & $200-300$ & 259 & \multirow{2}{*}{$\mathrm{CoO}$} & Two nitrate ions & 14.98 & 15.01 \\
\hline & II & $300-600$ & 521 & & Two molecules of ATAC & 69.76 & 70.16 \\
\hline
\end{tabular}

ion and the DTG peak appears at $361{ }^{\circ} \mathrm{C}$. One iodide ion and one molecule of ATAC decomposes in the second stage, which starts at $390{ }^{\circ} \mathrm{C}$ and ends at $490{ }^{\circ} \mathrm{C}$ (mass loss $65.1 \%$ ) with a DTG peak $425^{\circ} \mathrm{C}$. The final residue above $490{ }^{\circ} \mathrm{C}$ is found to be $\mathrm{CoO}$.

From the TG curve of nitrato complex, it is evident that the complex is stable up to $290^{\circ} \mathrm{C}$. No mass loss up to this temperature indicates the absence of water or solvent molecule. The complex undergoes two stage decomposition pattern, in which first stage starts at $290{ }^{\circ} \mathrm{C}$ and ends at $300{ }^{\circ} \mathrm{C}$ corresponding to the mass loss of two nitrate ions $(14.98 \%)$. The DTG peak appears at $259{ }^{\circ} \mathrm{C}$. The second stage $300-600{ }^{\circ} \mathrm{C}$ mass loss is found to be $69.76 \%$, which corresponds to the decomposition of two ligand molecule. DTG peak appears at $521{ }^{\circ} \mathrm{C}$. The final residue is found to be anhydrous $\mathrm{CoO}$.

From the thermal analysis data of four of the Co(II) complexes, it is observed that the chloro complex decomposes in one stage and bromo complex undergoes three stage decomposition, the iodo and nitrato complexes undergo a two stage decomposition pattern. The mass loss found is in good agreement with the calculated values. Observing the temperature of first weight loss of the complexes, it can be shown that within the series, the chloro and bromo complexes are the most stable ones and nitrate complex is least stable. The thermal stability of the complex varies in the order: chloride $=$ bromide $>$ iodide $>$ nitrate.

\section{Antimicrobial analyses}

Antibacterial studies: The results of antibacterial analyses of $\mathrm{Co}$ (II) complexes are reported in Table-6. The values shown in the table indicates that the activity of Schiff base ligand become more pronounced when coordinated with Co(II) ion. The chelation effect on central metal ion enhances antibacterial activity of the complexes. Delocalization of $\pi$ electrons increases the lipophilicity of the metal ion and consequently, the metal complexes can easily penetrate into the lipid membranes [36]. It is clear that the increase in antibacterial activity ATAC and complexes are in the order: $\left[\mathrm{Co}(\mathrm{ATAC}) \mathrm{Cl}_{2}\right]>\left[\mathrm{Co}(\mathrm{ATAC}) \mathrm{Br}_{2}\right]$ $>\left[\mathrm{Co}(\mathrm{ATAC}) \mathrm{I}_{2}\right]>\left[\mathrm{Co}(\mathrm{ATAC})_{2}\left(\mathrm{ClO}_{4}\right)\right]\left(\mathrm{ClO}_{4}\right)>\left[\mathrm{Co}(\mathrm{ATAC})_{2}\right.$ $\left.\left(\mathrm{NO}_{3}\right)\right]\left(\mathrm{NO}_{3}\right)>$ ATAC. All the complexes show promising antibacterial activities compared to the ligand and antibiotic.

Antifungal analyses: The antifungal analysis results of $\mathrm{Co}$ (II) complexes are summarized in Table-7. All the complexes, except iodide complex, are showing a very good antifungal activity compared to the ligand ATAC. The increase in the

\begin{tabular}{lccc} 
TABLE-6 \\
ANTIBACTERIAL ACTIVITY OF ATAC AND ITS Co(II) \\
\multicolumn{4}{c}{ COMPLEXES [(ZONE OF INHIBITION-DIAMETER (mm)] } \\
\hline \multicolumn{1}{c}{ Compound } & B. subtilis & E. coli & S. typhi \\
\hline ATAC & 14 & 10 & 13 \\
{$\left[\right.$ Co(ATAC) $\left.\mathrm{Cl}_{2}\right]$} & 30 & 23 & 25 \\
$\left.[\text { Co(ATAC) })_{2}\right]$ & 28 & 18 & 22 \\
{$\left[\right.$ Co(ATAC) $\left.I_{2}\right]$} & 27 & 17 & 19 \\
$\left.[\text { Co(ATAC })_{2}\left(\mathrm{NO}_{3}\right)\right]\left(\mathrm{NO}_{3}\right)$ & 25 & 20 & 20 \\
$\left.[\text { Co(ATAC })_{2}\left(\mathrm{ClO}_{4}\right)\right]\left(\mathrm{ClO}_{4}\right)$ & 26 & 19 & 17 \\
Antibiotic & 10 & 7 & 8 \\
DMSO & 0 & 0 & 0 \\
\hline
\end{tabular}

TABLE-7

ANTIFUNGAL ACTIVITY OF ATAC AND ITS Co(II) COMPLEXES [ZONE OF INHIBITION-DIAMETER (mm)]

\begin{tabular}{lccc}
\hline \multicolumn{1}{c}{ Compound } & A. fumigatus & A. niger & P. expansum \\
\hline ATAC & 12 & 0 & 13 \\
{$\left[\mathrm{Co}(\mathrm{ATAC}) \mathrm{Cl}_{2}\right]$} & 0 & 16 & 19 \\
{$\left[\mathrm{Co}(\mathrm{ATAC}) \mathrm{Br}_{2}\right]$} & 23 & 16 & 16 \\
{$\left[\mathrm{Co}(\mathrm{ATAC}) \mathrm{I}_{2}\right]$} & 0 & 0 & 18 \\
{$\left[\mathrm{Co}(\mathrm{ATAC})_{2}\left(\mathrm{NO}_{3}\right)\right]\left(\mathrm{NO}_{3}\right)$} & 20 & 16 & 19 \\
{$\left[\mathrm{Co}(\mathrm{ATAC})_{2}\left(\mathrm{ClO}_{4}\right)\right]\left(\mathrm{ClO}_{4}\right)$} & 19 & 14 & 15 \\
Antibiotic & 13 & 21 & 17 \\
DMSO & 0 & 0 & 0 \\
\hline
\end{tabular}

activity of the complexes compared to ATAC, can be explained by chelation theory. According to this theory, the decrease in polarizability of the metal increases the lipophilicity of the complexes. The decrease in polarity of the metal ion, by chelation, is mainly due to the partial sharing of positive charge with the donor atoms in the ligand and the delocalization of the $\pi$-electron over the whole molecule. This increase in lipophilic character may cause the breakdown of permeability barrier of the cells in fungus resulting in some disturbances with normal cell process [36]. It can be seen that the antifungal activity of the $\mathrm{Co}(\mathrm{III})$ complexes is follows the order: $\left[\mathrm{Co}(\mathrm{ATAC}) \mathrm{Br}_{2}\right]>$ $\left[\mathrm{Co}(\mathrm{ATAC})_{2}\left(\mathrm{NO}_{3}\right)\right]\left(\mathrm{NO}_{3}\right)>\left[\mathrm{Co}(\mathrm{ATAC})_{2}\left(\mathrm{ClO}_{4}\right)\right]\left(\mathrm{ClO}_{4}\right)>$ $\left[\mathrm{Co}(\mathrm{ATAC}) \mathrm{Cl}_{2}\right]>\left[\mathrm{Co}(\mathrm{ATAC}) \mathrm{I}_{2}\right]$.

DNA binding analyses: The DNA binding studies of Co(II) complexes of ATAC has been examined by absorption and fluorescence spectra and viscosity measurements.

Electronic spectral studies: Electronic absorption spectroscopy is an effective method to determine the DNA binding ability of metal complexes. Since intercalative mode of interaction involve strong stacking interaction between aromatic chromophore and the base pairs of DNA, binding of complex to 
DNA through intercalation results in hypochromism [37]. DNA binding nature of the synthesized $\mathrm{Co}$ (II) complexes of ATAC $\left\{\left[\mathrm{Co}(\mathrm{ATAC}) \mathrm{Cl}_{2}\right],\left[\mathrm{Co}(\mathrm{ATAC}) \mathrm{Br}_{2}\right],\left[\mathrm{Co}(\mathrm{ATAC})_{2}\left(\mathrm{NO}_{3}\right)\right]\left(\mathrm{NO}_{3}\right)\right.$ and $\left.\left[\mathrm{Co}(\mathrm{ATAC})_{2}\left(\mathrm{ClO}_{4}\right)\right]\left(\mathrm{ClO}_{4}\right)\right\}$ with CT-DNA were determined by measuring absorption changes in the absence and presence of DNA. Absorption titration experiments were carried out by a fixed concentration of the complex $(25 \mu \mathrm{M})$ with gradually increasing concentration of DNA (10-50 $\mu \mathrm{M})$. Figs. 1-4 show the absorption spectra of complexes with DNA. The binding of complexes to CT-DNA led to hypochromism, i.e., a decrease in the absorption intensity. The reason for this observation is that, after intercalating the base pairs of DNA, the $\pi$ orbital of the base pairs can couple with $\pi^{*}$ orbital of the intercalated ligand, thus decreasing the $\pi \rightarrow \pi^{*}$ transition energy [38]. In order to evaluate the binding strength of complexes towards CT-DNA, the intrinsic binding constants $\left(\mathrm{K}_{\mathrm{b}}\right)$ of the complexes were determined by observing the absorbance at $325 \mathrm{~nm}$ by using the following equation [39]:

$$
\frac{[D N A]}{\left(\varepsilon_{\mathrm{a}}-\varepsilon_{\mathrm{f}}\right)}=\frac{[\mathrm{DNA}]}{\left(\varepsilon_{\mathrm{b}}-\varepsilon_{\mathrm{f}}\right)}+\frac{1}{\mathrm{~K}_{\mathrm{b}}\left(\varepsilon_{\mathrm{b}}-\varepsilon_{\mathrm{f}}\right)}
$$

where [DNA] is the concentration of DNA and the apparent absorption coefficient $\left(\varepsilon_{\mathrm{a}}\right)$, corresponds to $\mathrm{A}_{\mathrm{obs}} /\left[\right.$ complex]. $\varepsilon_{\mathrm{f}}$ refers to the extinction coefficient of the free complex and $\varepsilon_{\mathrm{b}}$ is the extinction coefficient of the complex fully bound to DNA. We can determine the slope and intercept of the plot of [DNA]/ $\left(\varepsilon_{\mathrm{a}}-\varepsilon_{\mathrm{f}}\right)\left(\times 10^{-9}\right) v s$. [DNA] (Fig. 5), which is equal to $1 / \varepsilon_{\mathrm{b}}-\varepsilon_{\mathrm{f}}$ and $1 / K_{b}\left(\varepsilon_{b}-\varepsilon_{f}\right)$ respectively. Thus $K_{b}$ is the ratio of slope to

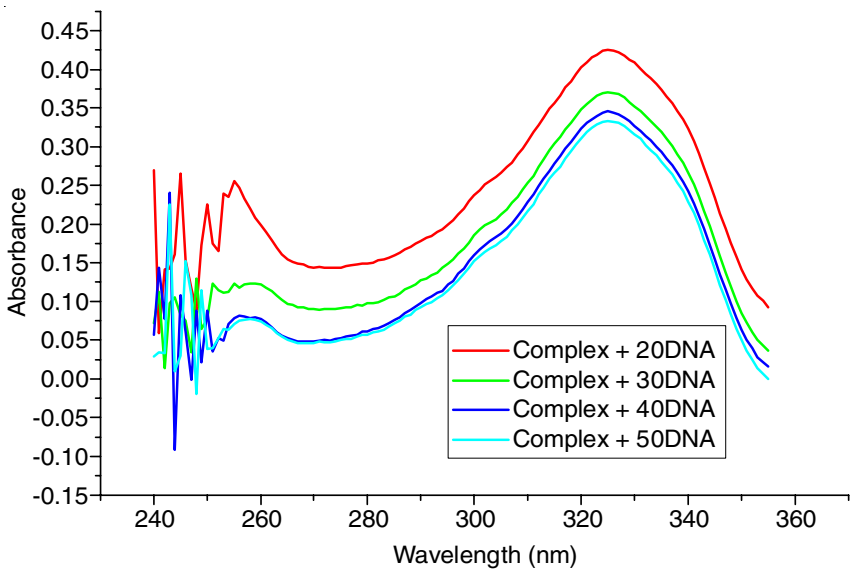

Fig. 1. Absorption spectra of $\mathrm{Co}(\mathrm{II})$ chloride complexes

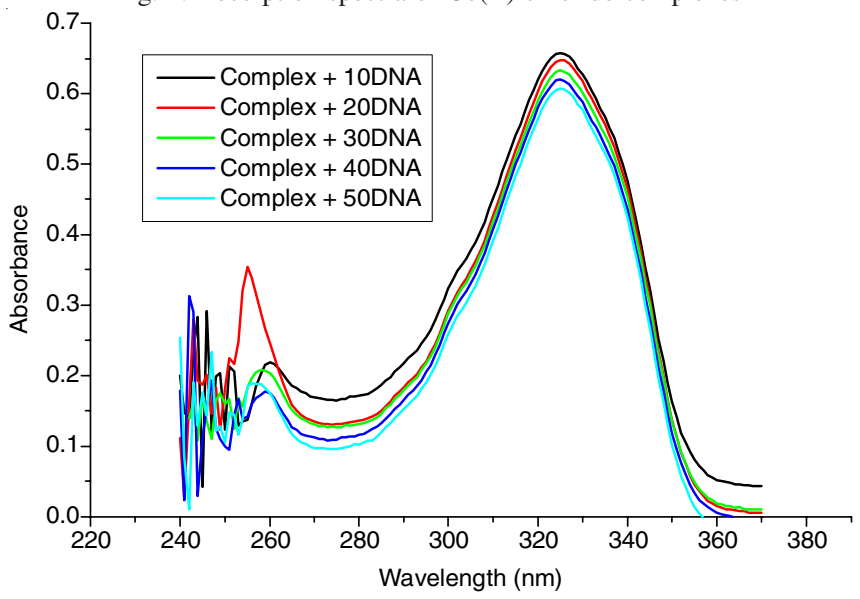

Fig. 2. Absorption spectra of $\mathrm{Co}(\mathrm{II})$ bromide complexes

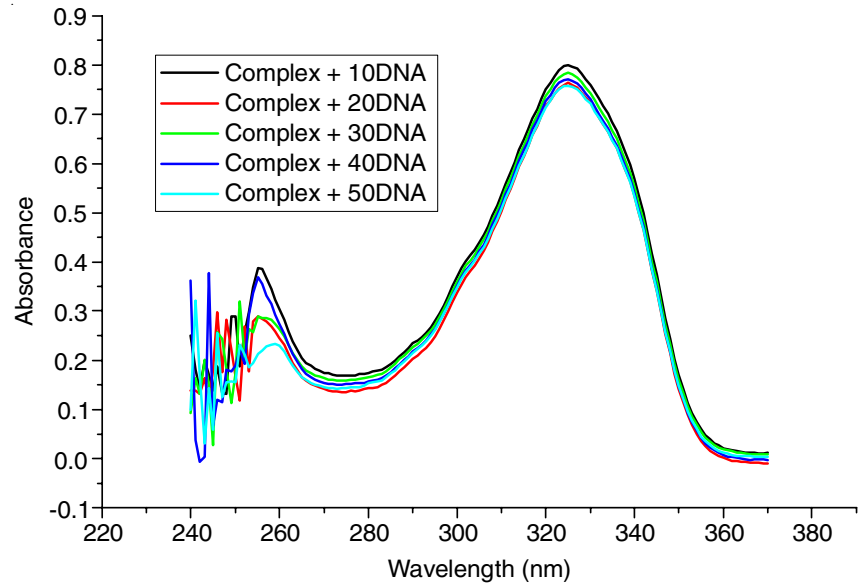

Fig. 3. Absorption spectra of Co(II) nitrate complexes

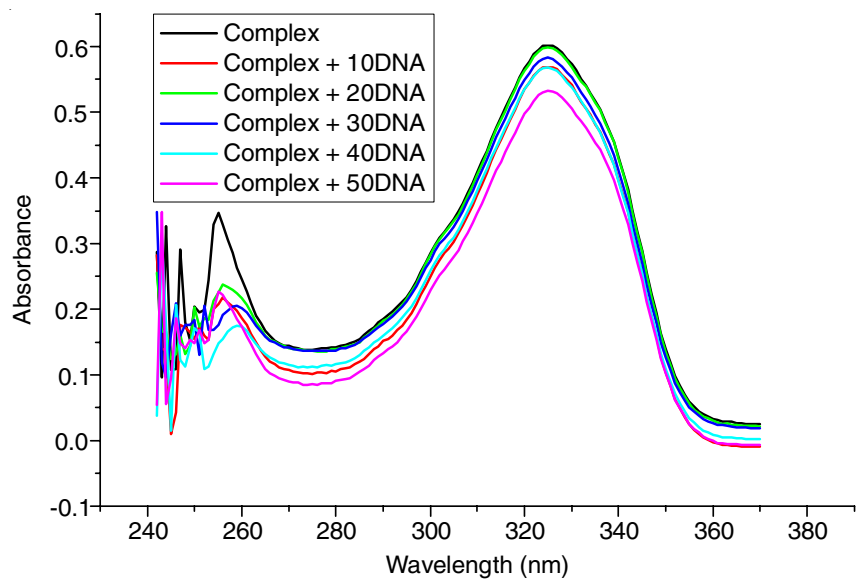

Fig. 4. Absorption spectra of Co(II) perchlorate complex $[\mathrm{DNA}] /\left(\varepsilon_{\mathrm{a}^{-}} \varepsilon_{\mathrm{f}}\right)$ $\left(\times 10^{-9}\right)$

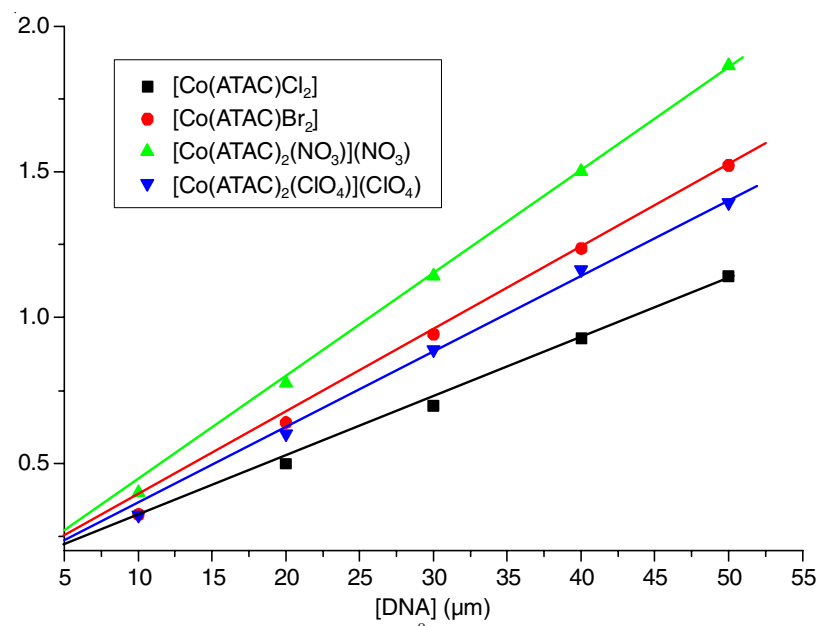

Fig. 5. Plot of $[\mathrm{DNA}] /\left(\varepsilon_{\mathrm{a}^{-}} \varepsilon_{\mathrm{f}}\right)\left(\times 10^{-9}\right)$ versus [DNA] for the complexes of ATAC of $\mathrm{Co}(\mathrm{II})$

the intercept. The binding constants $\mathrm{K}_{\mathrm{b}}$ for the Co(II) complexes are calculated and found to be $4.6 \times 10^{4} \mathrm{M}^{-1}, 1.33 \times 10^{5}$ $\mathrm{M}^{-1}, 1.38 \times 10^{5} \mathrm{M}^{-1}$ and $1.24 \times 10^{5} \mathrm{M}^{-1}$, respectively for [Co(ATAC) $\left.\mathrm{Cl}_{2}\right],\left[\mathrm{Co}(\mathrm{ATAC}) \mathrm{Br}_{2}\right],\left[\mathrm{Co}(\mathrm{ATAC})_{2}\left(\mathrm{NO}_{3}\right)\right]\left(\mathrm{NO}_{3}\right)$ and $\left[\mathrm{Co}(\mathrm{ATAC})_{2}\left(\mathrm{ClO}_{4}\right)\right]\left(\mathrm{ClO}_{4}\right)$ complexes. The obtained $\mathrm{K}_{\mathrm{b}}$ values are in good agreement with those of intercalative DNA binding of Schiff base Co(II) complexes [40]. From the $\mathrm{K}_{\mathrm{b}}$ values the binding ability of the complexes follows the order: $\left[\mathrm{Co}(\mathrm{ATAC})_{2}\left(\mathrm{NO}_{3}\right)\right]\left(\mathrm{NO}_{3}\right)>\left[\mathrm{Co}(\mathrm{ATAC}) \mathrm{Br}_{2}\right]>\left[\mathrm{Co}(\mathrm{ATAC})_{2}\left(\mathrm{ClO}_{4}\right)\right]$ $\left(\mathrm{ClO}_{4}\right)>\left[\mathrm{Co}(\mathrm{ATAC}) \mathrm{Cl}_{2}\right]$. 
Fluorescence measurements: To confirm the interaction between the complexes and CT-DNA, an ethidium bromide (EB) fluorescence displacement experiment was carried out. Quenching of the fluorescence of ethidium bromide bound to DNA were determined with increasing amount of metal complexes as a second molecule. The addition of the complexes to DNA pre-treated with ethidium bromide causes considerable reduction in emission intensity, indicating the complexes compete with ethidium bromide in binding to DNA. Figs. 6-9 show the fluorescence emission spectra of the EB-DNA solution upon titration with $\mathrm{Co}(\mathrm{II})$ complexes, $\left[\mathrm{Co}(\mathrm{ATAC}) \mathrm{Cl}_{2}\right]$, [Co(ATAC) $\left.\mathrm{Br}_{2}\right]$, [Co(ATAC) $\left.)_{2}\left(\mathrm{NO}_{3}\right)\right]\left(\mathrm{NO}_{3}\right)$ and $\left[\mathrm{Co}(\mathrm{ATAC})_{2}\left(\mathrm{ClO}_{4}\right)\right]$ $\left(\mathrm{ClO}_{4}\right)$. From the figure it is clear that, as the concentration of the complex increases, the emission band at $385 \mathrm{~nm}$ show

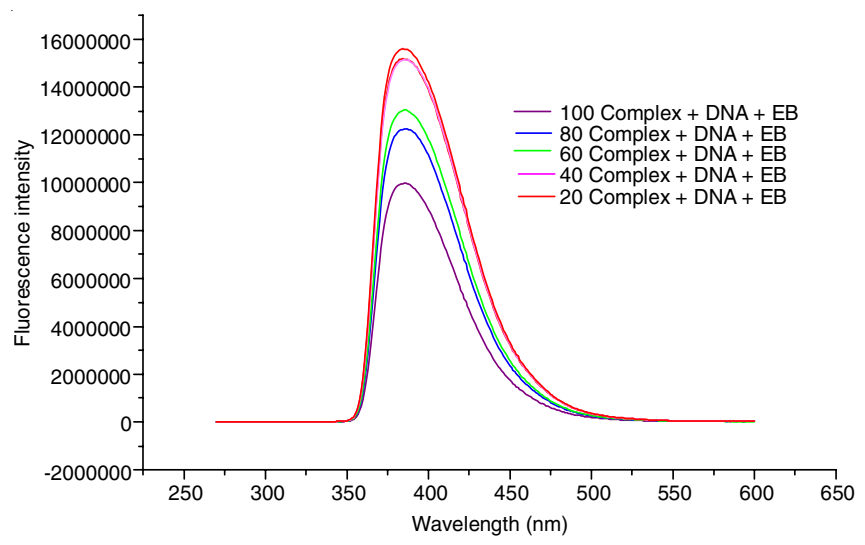

Fig. 6. Fluorescence emission spectra of chloride complex of Co(II)

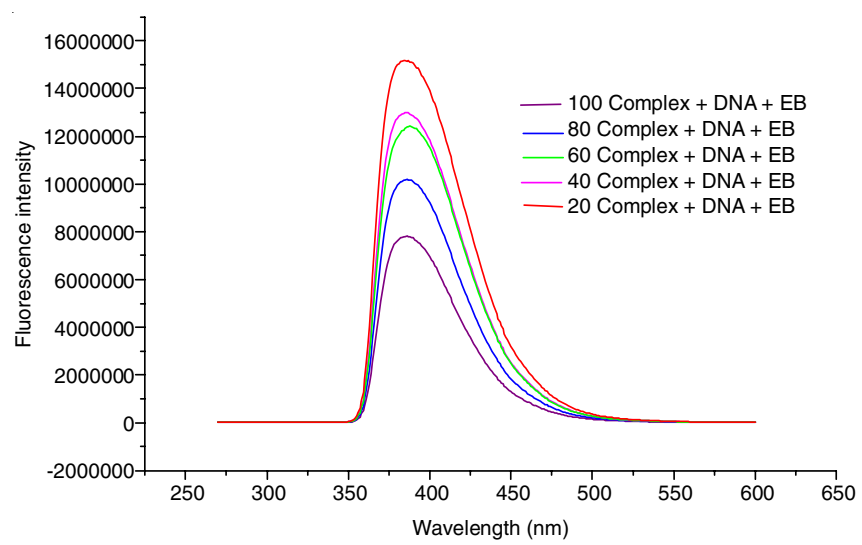

Fig. 7. Fluorescence emission spectra of bromide complex of Co(II)

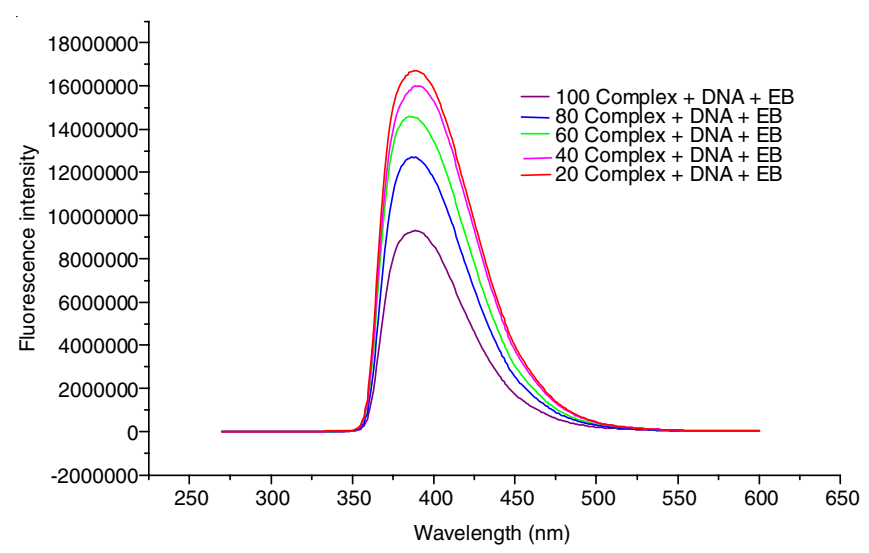

Fig. 8. Fluorescence emission spectra of nitrate complex of $\mathrm{Co}$ (II)

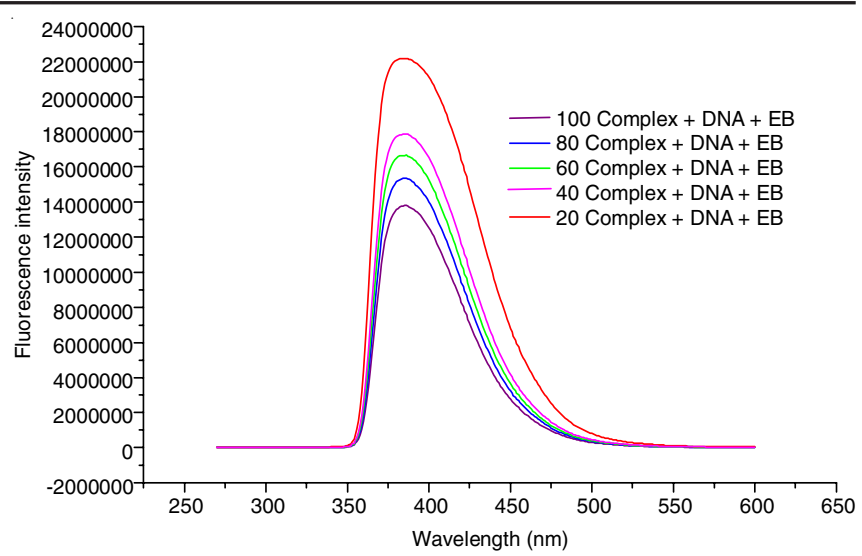

Fig. 9. Fluorescence emission spectra of perchlorate complexes of Co(II)

hypochromism up to $30 \%$ of the initial fluorescence intensity. The observed decrease in the fluorescence intensity indicates that the ethidium bromide molecules are displaced from their binding sites and are replaced by the complexes.

Quenching data were analyzed according to the SternVolmer [41] equation:

$$
\mathrm{F}_{0} / \mathrm{F}=\mathrm{K}_{\mathrm{sv}}[\mathrm{Q}]+1
$$

where, $\mathrm{F}_{0}$ is the emission intensity in the absence of complex and $\mathrm{F}$ is the emission intensity in the presence of complex, $\mathrm{K}_{\mathrm{sv}}$ is the quenching constant (Stern-Volmer constant) and [Q] is the quencher (complex) concentration. Plotting the ratio of emission intensities $\mathrm{F}_{0} / \mathrm{F}$ against $[\mathrm{Q}]$, the complex concentration, gives a linear Stern-Volmer plot, which describes the quenching process. $\mathrm{K}_{\mathrm{sv}}$ value is obtained from the slope of the plotted line. The quenching plots are in good agreement with the linear Stern-Volmer equation. The quenching constants $\mathrm{K}_{\mathrm{sv}}$ for the $\mathrm{Co}(\mathrm{II})$ complexes were calculated from the slope of the Stern-Volmer plots (Figs. 10 and 11 ) of $\mathrm{F}_{0} / \mathrm{F}$ versus [Q]. The $\mathrm{K}_{\mathrm{sv}}$ values for the complexes [Co(ATAC) $\mathrm{Cl}_{2}$ ], [Co(ATAC) $\mathrm{Br}_{2}$ ], $\left[\mathrm{Co}(\mathrm{ATAC})_{2}\left(\mathrm{NO}_{3}\right)\right]\left(\mathrm{NO}_{3}\right)$ and $\left[\mathrm{Co}(\mathrm{ATAC})_{2}\left(\mathrm{ClO}_{4}\right)\right]\left(\mathrm{ClO}_{4}\right)$ were found to be $6.05 \times 10^{2} \mathrm{M}^{-1}, 1.56 \times 10^{3} \mathrm{M}^{-1}, 7.04 \times 10^{3} \mathrm{M}^{-1}$ and $9.85 \times 10^{2} \mathrm{M}^{-1}$, respectively. From the above results it can be concluded that the interaction of nitrato complex with CT-DNA is stronger than other complexes and the quenching constant suggest that the interaction of the complexes with DNA should be intercalation [11-13,38].

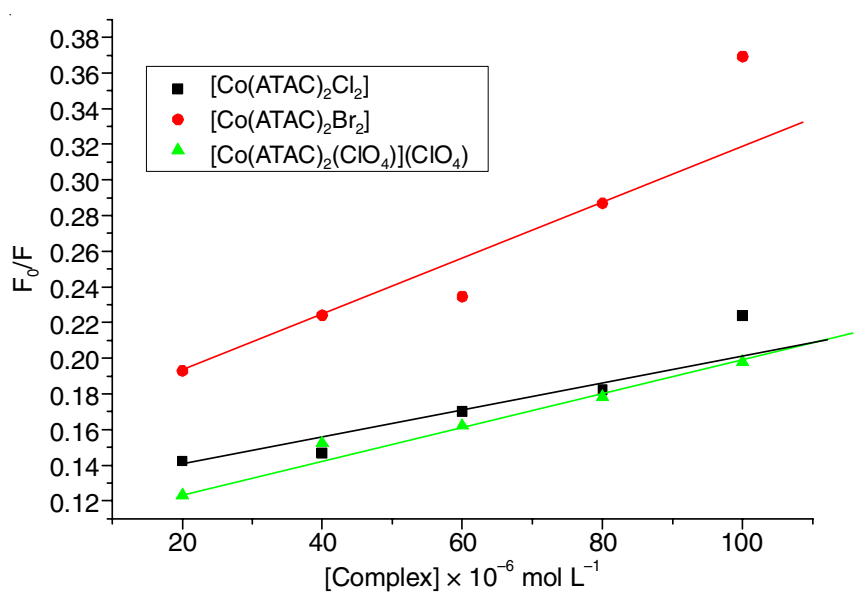

Fig. 10. Stern-Volmer plots of the fluorescence titrations for the Co(II) complexes of ATAC 


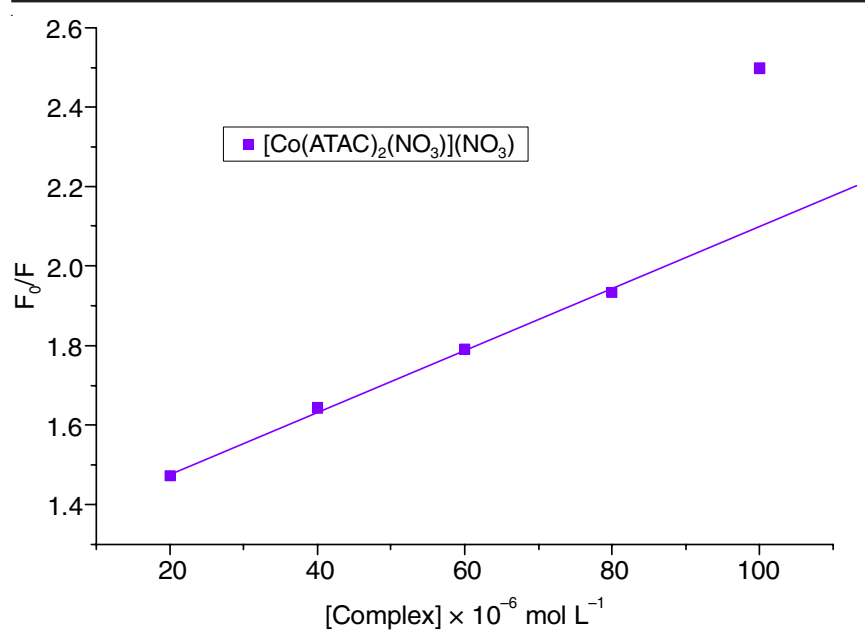

Fig. 11. Stern-Volmer plots of fluorescence titrations for $\left[\mathrm{Co}(\mathrm{ATAC})\left(\mathrm{NO}_{3}\right)\right]\left(\mathrm{NO}_{3}\right)$

Viscosity studies: In the absence of crystallographic data or NMR, viscosity and sedimentation measurements, that are sensitive to length change, are regarded as the most critical tests of binding model in solution [42]. As a means for further confirmation of the interaction between complexes and DNA, viscosity measurements were done at room temperature. A classical intercalation model results in an increase of DNA viscosity due to the lengthening of DNA helix, as base pairs are separated to hold the binding ligand. A partial or non-classical intercalation of ligand may bend the DNA helix, resulting in the decrease of its length and also its viscosity [43]. In the present study, all the $\mathrm{Co}$ (II) complexes were found to increase the viscosity of DNA (Fig. 12). The increase in viscosity suggests that the complexes could bind to DNA by the intercalation mode $[44,45]$.

\section{Conclusion}

According to the data obtained from elemental analysis and molar conductance measurement, the five complexes of $\mathrm{Co}$ (II) may be formulated as, [Co(ATAC) $\left.\mathrm{Cl}_{2}\right]$, [Co(ATAC) $\mathrm{Br}_{2}$ ], $\left[\mathrm{Co}(\mathrm{ATAC}) \mathrm{I}_{2}\right],\left[\mathrm{Co}(\mathrm{ATAC})_{2}\left(\mathrm{NO}_{3}\right)\right]\left(\mathrm{NO}_{3}\right)$ and $\left[\mathrm{Co}(\mathrm{ATAC})_{2}\left(\mathrm{ClO}_{4}\right)\right]$ $\left(\mathrm{ClO}_{4}\right)$. The information obtained from the infrared spectra reveals that the Schiff base ligand ATAC act as a neutral bidentate ligand coordinating through pyrazolone carbonyl oxygen and azomethine nitrogen. The infrared spectral data and molar conductance measurements indicate that the two anions are directly coordinated in chloride, bromide and iodide complexes. In nitrate and perchlorate complexes, one of the anion is coordinated bidentately and

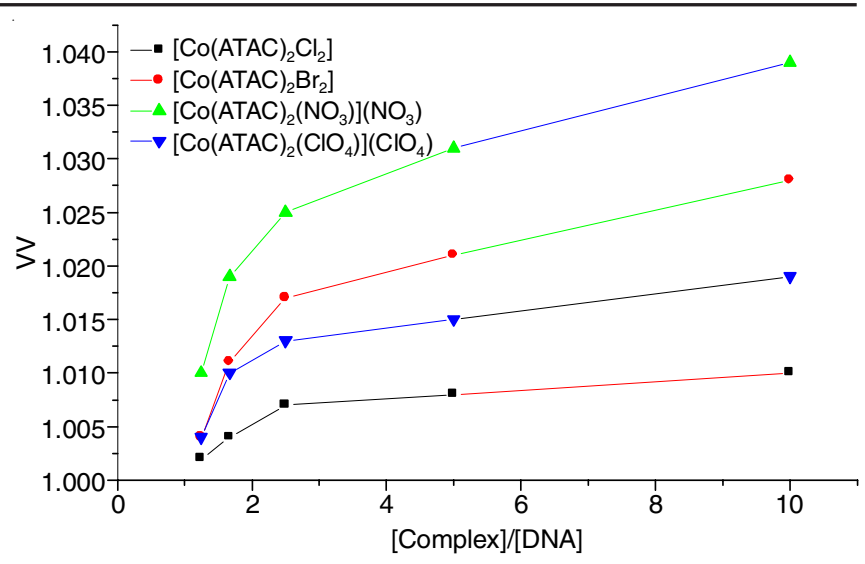

Fig. 12. Effect of increasing amounts of Co(II) complexes of ATAC on the relative viscosity of CT-DNA

the other one remains as counter anion. The UV-visible spectra and magnetic susceptibility data propose a tetrahedral geometry around the Co(II) ion in chloride, bromide and iodide complexes while an octahedral geometry in nitrate and perchlorate complexes. Thermogravimetric analysis of four complexes of Co(II) was investigated. The observed and calculated mass loss is in good agreement with a final residue $\mathrm{CoO}$. The thermal stability of the complexes is in the order: chloride $=$ bromide $>$ iodide $>$ nitrate. Antimicrobial studies shows that all complexes show enhanced activity when compared to the ligand. Considering DNA binding, from the absorption spectral analysis of the complexes with increased concentration of CT-DNA, it can be seen that, there is a decrease in absorption intensities. This indicates that the complexes bind the DNA through intercalation. This observation is confirmed with fluorescence spectra and viscosity measurements. Based on the results of the present study, tentative structures were assigned to the complexes and shown in Fig. 13.

\section{ACKNOWLEDGEMENTS}

The authors are thankful to School of Chemical Sciences, Mahatma Gandhi University, Kottayam, for spectral analyses India.

\section{CONFLICT OF INTEREST}

The authors declare that there is no conflict of interests regarding the publication of this article.

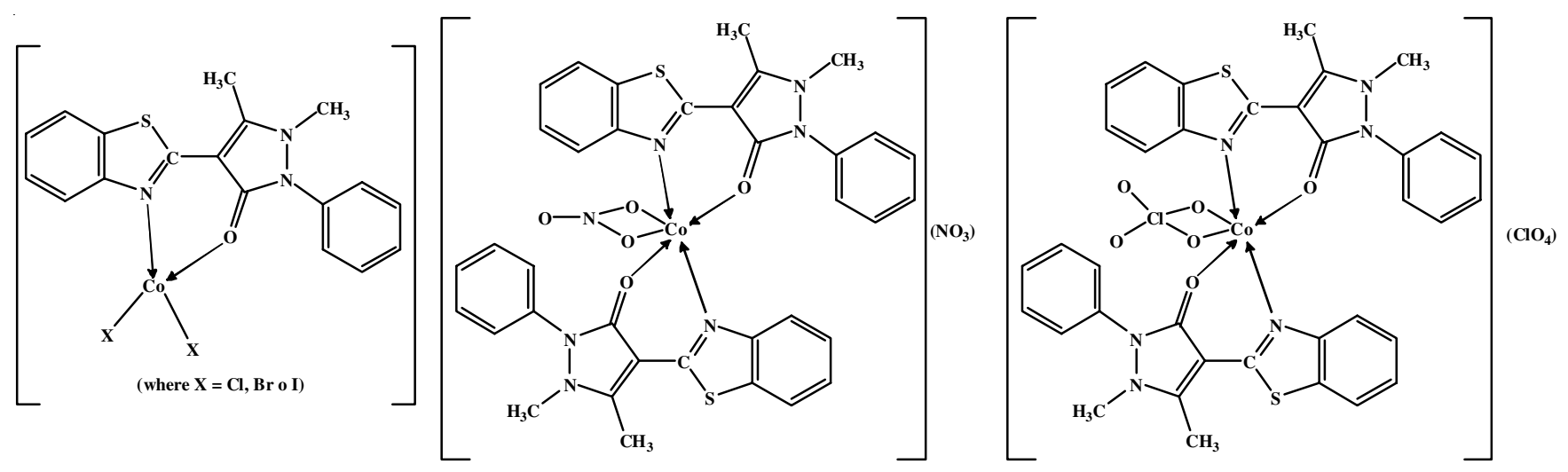

Fig. 13. Tentative structures of Co(II) complexes of ATAC 


\section{REFERENCES}

1. J. Thakurta, J. Chakraborty, G. Rosair, R.J. Butcher and S. Mitra, Inorg. Chim. Acta, 362, 2828 (2009); https://doi.org/10.1016/j.ica.2009.01.002.

2. D.N. Dhar and C. Taploo, J. Sci. Ind. Res. (India), 41, 501 (1982).

3. M. Nishio, M. Matsuda, F. Ohyanagi, Y. Sato, S. Okumura, D. Tabata, A. Morikawa, K. Nakagawa and T. Horai, Lung Cancer, 49, 245 (2005); https://doi.org/10.1016/j.lungcan.2005.02.007.

4. S. Bondock, R. Rabie, H.A. Etman and A.A. Fadda, Eur. J. Med. Chem., 43, 2122 (2008); https://doi.org/10.1016/j.ejmech.2007.12.009.

5. S. Cunha, S.M. Oliveira, M.T. Rodrigues Jr., R.M. Bastos, J. Ferrari, C.M. de Oliveira, L. Kato, H.B. Napolitano, I. Vencato and C. Lariucci, J. Mol. Struct., 752, 32 (2005); https://doi.org/10.1016/j.molstruc.2005.05.016.

6. M. Mahmoud, R. Abdel-Kader, M. Hassanein, S. Saleh and S. Botros, Eur. J. Pharmacol., 569, 222 (2007); https://doi.org/10.1016/j.ejphar.2007.04.061.

7. G. Turan-Zitouni, M. Sivaci, F.S. Kiliç and K. Erol, Eur. J. Med. Chem., 36, 685 (2001);

https://doi.org/10.1016/S0223-5234(01)01252-1.

8. A.E. Rubtsov, R.R. Makhmudov, N.V. Kovylyaeva, N.I. Prosyanik, A.V. Bobrov and V.V. Zalesov, Pharm. Chem. J., 36, 608 (2002); https://doi.org/10.1023/A:1022669432631.

9. A.I. Vogel, A Text Book of Quantitative Inorganic Analysis, ELBS: London (1961).

10. E. Kurz, G. Kober and M. Berl, Anal. Chem., 30, 1983 (1958); https://doi.org/10.1021/ac60144a030.

11. D. Senthil Raja, N.S.P. Bhuvanesh and K. Natarajan, J. Biol. Inorg. Chem., 17, 223 (2012); https://doi.org/10.1007/s00775-011-0844-1.

12. Z.C. Liu, B.D. Wang, Z.Y. Yang, Y. Li, D.D. Qin and T.R. Li, Eur. J. Med. Chem., 44, 4477 (2009); https://doi.org/10.1016/j.ejmech.2009.06.009.

13. Z.C. Liu, B.D. Wang, B. Li, Q. Wang, Z.Y. Yang, T.R. Li and Y. Li, Eur. J. Med. Chem., 45, 5353 (2010); https://doi.org/10.1016/j.ejmech.2010.08.060.

14. D.S. Raja, N.S.P. Bhuvanesh and K. Natarajan, Dalton Trans., 41, 4365 (2012); https://doi.org/10.1039/c2dt12274j.

15. J. Liu, T. Zhang, T. Lu, L. Qu, H. Zhou, Q. Zhang and L. Ji, J. Inorg. Biochem., 91, 269 (2002); https://doi.org/10.1016/S0162-0134(02)00441-5.

16. W.J. Geary, Coord. Chem. Rev., 7, 81 (1971); https://doi.org/10.1016/S0010-8545(00)80009-0.

17. R.N. Jadeja and J.R. Shah, Polyhedron, 26, 1677 (2007); https://doi.org/10.1016/j.poly.2006.12.016.

18. P.M. Vimal Kumar and P.K. Radhakrishnan, Polyhedron, 29, 2335 (2010); https://doi.org/10.1016/j.poly.2010.05.010.

19. N.T. Madhu and P.K. Radhakrishnan, Transition Met. Chem., 25, 287 (2000); https://doi.org/10.1023/A:1007011724307.

20. M. Alaudeen and P.K. Radhakrishnan, Synth. React. Inorg. Met.-Org. Nano-Met. Chem., 20, 673 (1990); https://doi.org/10.1080/00945719008048164.

21. N.T. Madhu and P.K. Radhakrishnan, Synth. React. Inorg. Met.-Org. Nano-Met. Chem., 31, 1663 (2001); https://doi.org/10.1081/SIM-100107711.

22. C.R. Vinodkumar and P.K. Radhakrishnan, Synth. React. Inorg. Met.Org. Chem., 27, 1365 (1997); https://doi.org/10.1080/00945719708000164.

23. K. Nakomoto, Infrared and Raman Spectra of Inorganic and Coordination Compounds, Wiley: New York (1986).
24. R.K. Agarwal, B. Prakash, V. Kumar and A.A. Khan, J. Iran Chem. Soc., 4, 114 (2007); https://doi.org/10.1007/BF03245809.

25. R.B. Bennie, S.T. David, M. Sivthasaki, S.A.J. Mary, M. Seethalakshmi, S.D. Abraham, C. Joel and R. Antony, Chem. Sci. Trans., 33, 937 (2014); https://doi.org/10.7598/cst2014.805.

26. E. Pahontu, V. Fala, A. Gulea, D. Poirier, V. Tapcov and T. Rosu, Molecules, 18, $8812(2013)$; https://doi.org/10.3390/molecules 18088812 .

27. T.M. Aminabhavi, N.S. Biradar, M.C. Divakar and W.E. Rudzinski, Inorg. Chim. Acta, 92, 99 (1984); https://doi.org/10.1016/S0020-1693(00)80005-5.

28. B.N. Ghose and K.M. Lasisi, Synth. React. Inorg. Met.-Org. Nano-Met. Chem., 16, 1189 (1986); https://doi.org/10.1080/00945718608071386.

29. L.K. Thompson, J.C.T. Rendell and G.C. Wellon, Can. J. Chem., 60, 514 (1982); https://doi.org/10.1139/v82-075.

30. A.B.P. Lever, Inorganic Electronic Spectroscopy, Elsevier: Amsterdam, edn 2 (1984).

31. S. Dehghanpour and A. Mahmoudi, Synth. React. Inorg. Met.-Org. Chem., 37, 35 (2007); https://doi.org/10.1080/15533170601172427.

32. M. Amirnasr, A.H. Mahmoudkhani, A. Gorji, S. Dehghanpour and H.R. Bijanzadeh, Polyhedron, 21, 2733 (2002); https://doi.org/10.1016/S0277-5387(02)01277-9.

33. A. Sousa-Pedrares, N. Camiña, J. Romero, M.L. Durán, J.A. GarcíaVázquez and A. Sousa, Pohyhedron, 27, 3391 (2008); https://doi.org/10.1016/j.poly.2008.08.011.

34. M. del Carmen Fernández-Fernández, R.B. de la Calle, A. Macías, L.V. Matarranz and P. Pérez-Lourido, Polyhedron, 27, 2301 (2008); https://doi.org/10.1016/j.poly.2008.04.043.

35. M. Tuncel and S. Serin, Transition Met. Chem., 31, 805 (2006); https://doi.org/10.1007/s11243-006-0074-5.

36. S. Chandra and A. Kumar, Spectrochim. Acta A Mol. Biomol. Spectrosc., 68, 1410 (2007); https://doi.org/10.1016/j.saa.2006.12.079.

37. J.K. Barton, A.T. Danishefsky and J.M. Goldberg, J. Am. Chem. Soc., 106, 2172 (1984); https://doi.org/10.1021/ja00319a043.

38. M. Shebl, Spectrochim. Acta A Mol. Biomol. Spectrosc., 117, 127 (2014); https://doi.org/10.1016/j.saa.2013.07.107.

39. V. Uma, M. Kanthimathi, T. Weyhermuller and B.U. Nair, J. Inorg. Biochem., 99, 2299 (2005); https://doi.org/10.1016/j.jinorgbio.2005.08.011.

40. S. Anbu and M. Kandaswamy, Polyhedron, 30, 123 (2011); https://doi.org/10.1016/j.poly.2010.09.041.

41. S.O. Bahaffi, A.A. Abdel Aziz and M.M. El-Naggar, J. Mol. Struct., 1020, 188 (2012); https://doi.org/10.1016/j.molstruc.2012.04.017.

42. J.R. Lakowicz and G. Weber, Biochemistry, 12, 4161 (1973); https://doi.org/10.1021/bi00745a020.

43. H. Chao, W.-J. Mei, Q.-W. Huang and L.-N. Ji, J. Inorg. Biochem., 92 , 165 (2002); https://doi.org/10.1016/S0162-0134(02)00543-3.

44. S. Satyanarayana, J.C. Dabrowiak and J.B. Chaires, Biochemistry, 31, 9319 (1992); https://doi.org/10.1021/bi00154a001.

45. S. Satyanarayana, J.C. Dabrowiak and J.B. Chaires, Biochemistry, 32, 2573 (1993); https://doi.org/10.1021/bi00061a015. 